\title{
In silico identification and assessment of insecticide target sites in the genome of the small hive beetle, Aethina tumida
}

Frank D. Rinkevich ${ }^{*}$ (i) and Lelania Bourgeois

\begin{abstract}
Background: The small hive beetle, Aethina tumida, is a rapidly emerging global pest of honey bee colonies. Small hive beetle infestation can be extremely destructive, which may cause honey bees to abscond and render colony infrastructure unusable. Due to the impacts small hive beetles have on honey bees, a wide variety of physical, cultural, and chemical control measures have been implemented to manage small hive beetle infestations. The use of insecticides to control small hive beetle populations is an emerging management tactic. Currently, very little genomic information exists on insecticide target sites in the small hive beetle. Therefore, the objective of this study is to utilize focused in silico comparative genomics approaches to identify and assess the potential insecticide sensitivity of the major insecticide target sites in the small hive beetle genome.

Results: No previously described resistance mutations were identified in any orthologs of insecticide target sites. Alternative exon use and A-to-I RNA editing were absent in AtumSC1. The ryanodine receptor in small hive beetle (Atum_Ryr) was highly conserved and no previously described resistance mutations were identified. A total of 12 nAChR subunits were identified with similar alternative exon use in other insects. Alternative exon use and critical structural features of the GABA-gated chloride channel subunits (Atum_RDL, Atum_GRD, and Atum_LCCH3) were conserved. Five splice variants were found for the glutamate-gated chloride channel subunit. Exon $3 c$ of Atum GluCl may be a beetle-specific alternative exon. The co-occurrence of exons $9 \mathrm{a}$ and $9 \mathrm{~b}$ in the $\mathrm{pH}$-sensitive chloride channel (Atum_pHCl) is a unique combination that introduces sites of post-translational modification. The repertoire and alternative exon use for histamine-gated chloride channels (Atum-HisCl), octopamine (Atum_OctR) and tyramine receptors (Atum_TAR) were conserved.

Conclusions: The recently published small hive beetle genome likely serves as a reference for insecticidesusceptible versions of insecticide target sites. These comparative in silico studies are the first step in discovering targets that can be exploited for small hive beetle-specific control as well as tracking changes in the frequency of resistance alleles as part of a resistance monitoring program. Comparative toxicity alongside honey bees is required to verify these in silico predictions.
\end{abstract}

Keywords: Small hive beetle, Insecticide, Target-site, Honey bee, Pest management

\footnotetext{
* Correspondence: frank.rinkevich@usda.gov

USDA-ARS Honey Bee Breeding, Genetics, and Physiology Laboratory, Baton

Rouge, LA, USA
}

(c) The Author(s). 2020 Open Access This article is distributed under the terms of the Creative Commons Attribution 4.0 International License (http://creativecommons.org/licenses/by/4.0/), which permits unrestricted use, distribution, and reproduction in any medium, provided you give appropriate credit to the original author(s) and the source, provide a link to the Creative Commons license, and indicate if changes were made. The Creative Commons Public Domain Dedication waiver (http://creativecommons.org/publicdomain/zero/1.0/) applies to the data made available in this article, unless otherwise stated. 


\section{Background}

The small hive beetle (SHB), Aethina tumida, is a global pest of honey bee colonies that is rapidly expanding its presence outside of its native range in Sub-Saharan Africa to recently reported infestations in Brazil [1] and South Korea [2]. This dynamic worldwide distribution is a consequence of the global trade in beeswax products that are infested with SHB [3]. The SHB can feed on stored food resources (i.e. nectar, honey and pollen), all stages of honey bee brood, and even Tylosin treated patties used to control American foulbrood [4]. The impacts of SHB infestation are amplified by the symbiotic relationship with the yeast, Kodamaea ohmeri. This yeast ferments honey and pollen and produces volatiles which function as aggregation attractants and yields the characteristic slimy appearance and distinct odor of comb infested with SHB [5].

Honey bees are capable of preventing SHB colonization and infestation via hygienic or defensive behaviors [6]. Honey bee behaviors include running off adult beetles, removing eggs and larvae, or encasing adults in propolis jails in by the process of social encapsulation [7, 8]. Smaller nucleus honey bee colonies are more susceptible to failure due to SHB infestation compared to full sized colonies [9]. Honey bee genetics play a role in SHB infestation. Cape honey bees exhibit higher rates of aggressive behavior towards SHB than European honey bees [10]. Colonies of Russian honey bees tend to have fewer SHB than Italian honey bees [11].

Beekeepers implement cultural, physical, and chemical practices to reduce SHB infestation, with varying degrees of success. Maintaining colonies in sunny areas with low ambient humidity and low soil moisture limits the development and population of SHB [12]. The use of physical barriers, such as entrance reducers, may lower SHB infestation level [11]. Additionally, a wide variety of traps exist to control SHB populations, but very few have been demonstrated to enhance honey bee colony performance in terms of brood area, adult population, colony weight gain, or colony survival $[13,14]$. Thus, insecticide treatments are sought after as an alternative and effective SHB control measure. Currently in the USA, there are only two insecticides labelled for SHB control: coumaphos and permethrin. Coumaphos is an organophosphate that is sold as CheckMite $+{ }^{\mathrm{Tm}}$ and applied as strips within the colony. Permethrin is a pyrethroid that is sold as GardStar $^{\oplus}$ and labelled for use as a soil drench to control SHB that leave the colony as larvae to pupate in the soil. Should these or other insecticides be more intensely and more frequently used to control SHB, resistance to these materials will surely evolve as it has for coumaphos and tau-fluvalinate that are used to combat the important honey bee parasite, the Varroa mite (Varroa destructor) $[15,16]$.
Understanding the genetic basis of insecticide resistance is the foundation for designing an accurate, effective, and enduring resistance management strategy. A description of the SHB acetylcholinesterases (Ace1 and Ace2) and voltagegated sodium channel $\left(\mathrm{Na}_{\mathrm{v} 1}\right)$ have appeared in recent publications of the SHB genome [17] and transcriptome [18]. Ace and $\mathrm{Na}_{\mathrm{v} 1}$ are the target sites of organophosphate and pyrethroid insecticides, respectively, which are the only two classes of insecticide registered for SHB control in the USA. However, a wide variety of insecticides act at many other target sites in SHB.

Drosophila Sodium Channel 1 (DSC1 or NaCP60E) was thought to be a canonical voltage-gated sodium channel based upon structural comparison [19]. While true voltage-gated sodium channels possess a DEKA ion-selectivity motif that is highly selective for sodium ions, the DEEA ion-selectivity motif of DSC1 is much less selective and allows the conductance of a variety of cations $[20,21]$. Recent data on the neurophysiological properties of the honey bee DSC1 ortholog showed it was more closely related to calcium channels [22]. DSC1 is involved in odor detection [23], nervous system stability under stress [24], and insecticide sensitivity [24, 25] among other processes [26]. Orthologs of this channel are restricted to invertebrates [27].

The ryanodine receptor mediates the release of intracellular calcium from the endoplasmic reticulum of muscles and neurons resulting in $\mathrm{Ca}^{2+}$-dependent intracellular signaling cascades [28]. Diamide insecticides such as chlorantraniliprole (i.e. Rynaxapyr ${ }^{\mathrm{Ts}}$ ) specifically activate the ryanodine receptor $[29,30]$. These insecticides have extremely low toxicity to honey bees [31, 32].

The cys-loop ligand-gated ion channels (CLGIC) are a superfamily of receptors for the neurotransmitters acetylcholine, serotonin, gamma-amino butyric acid (GABA), glutamate, and glycine. CLGICs can form homo- or heteropentameric complexes with various combinations of subunits. All CLGIC subunits possess a cys-loop motif (i.e. $\mathrm{C}\left(\mathrm{X}_{13}\right) \mathrm{C}$ ) in the extracellular ligand binding domains and four transmembrane domains (TM1-4) with the second domain (TM2) forming the pore of the channel [33]. Insect nicotinic acetylcholine receptors (nAChRs) are important for learning and memory [34], as well as escape response [35]. They are also the target of neonicotinoid [36], sulfoximine [37], and spinosyn insecticides [38]. Mutations in nAChRs confer resistance to these insecticides [39, 40].

GABA-gated chloride channels are responsible for inhibitory currents in the insect central nervous system [41]. These receptors are the target sites of cyclodiene organochlorine (e.g. chlordane) and phenylpyrazole (e.g. fipronil) classes of insecticides that block receptor function [42]. Mutations in these receptors are responsible for resistance to these compounds [43]. Insects possess 
three GABA-gated chloride channel receptor subunits $[44,45]$. Although not labeled for use in the USA, Apithor ${ }^{\oplus}$ harborages are impregnated with fipronil and are effective at reducing SHB populations [14].

Avermectins (e.g. abamectin) are a class of insecticides that function as allosteric modulators of insect glutamate-gated chloride channels [41]. This class of insecticide is highly selective for insects, as mammals do not possess glutamate-gated chloride channels [46]. Mutations in the GluCl of Drosophila provide avermectin resistance in bioassays and heterologously-expressed receptors [47].

Despite $\mathrm{pH}$-sensitive chloride channels $(\mathrm{pHCl})$ possessing all the hallmarks of cys-loop ligand-gated ion channels, a systematic analysis showed that classic neurotransmitters were unable to elicit a response in heterologously-expressed receptors assembled from these genes [48]. Further investigation showed chloride currents in these channels are inhibited by low extracellular $\mathrm{pH}$ and induced by increased temperature and avermectin application. These $\mathrm{pHCls}$ appear to be restricted to arthropods [49].

Histamine is an important neurotransmitter that is involved in photoreception in insects [50]. Insects possess two genes that encode histamine-gated chloride receptors (HisCl1 and $\mathrm{HisCl} 2$, [44, 45, 48, 51]). Transcripts of these genes are highly expressed in the eye [52] and form pharmacologically and physiologically distinct homomeric receptors [48].

Octopamine and tyramine are phenolamines that act as neurotransmitters and neuromodulators in the insect nervous system that regulate complex behaviors such as grooming, courtship, feeding, learning, and memory [53, 54]. Octopamine and tyramine receptors are types of Gprotein coupled receptors that increase intracellular $\mathrm{Ca}^{2+}$ concentrations and/or activate molecular signaling cascades [54]. These receptors are the target sites for formamidine insecticides, such as amitraz that is used as a miticide to control Varroa mites in honey bee colonies $[55,56]$. Mutations in these receptors may underlie amitraz resistance $[57,58]$.

This manuscript utilizes in silico methods to describe the SHB orthologs that have been identified as target sites for most of the widely used and well-developed insecticide classes. These descriptions provide the comparative foundation to identify potential differences that can be exploited for SHB-specific control as well as to design a resistance monitoring program that will identify and track changes in resistance allele frequencies upon the application of insecticides used for SHB control.

\section{Results}

AtumSC1

The predicted protein for AtumSC1 (XP_019868698.1) possesses the characteristic DEEA selectivity filter and
MFL fast inactivation amino acid motifs as seen in other SC1 orthologs [20]. There were no optional exons in the predicted transcript (XM_020013139.1), although extensive optional exon usage is observed on other orthologs [24]. No A-to-I RNA editing events in AtumSC1 were identified, although SC1 orthologs undergo A-to-I RNA editing in other species [26]. Reduced sensitivity to DDT is conferred by an aspartic acid to asparagine mutation at position 1924 in DSC1 (D1924N, [59]). The aspartic acid residue in DSC1 is a threonine (T1924) in AtumSC1, as it is in orthologs in Tribolium (XP 015837606.1), honey bee (XP_006572013.1), bumble bee (XP_012173372.1) and carpenter ant (EFN62327.1). Therefore, it is unlikely if T1924 in AtumSC1 can modulate insecticide sensitivity or be exploited for speciesspecific control of SHB.

\section{Ryanodine receptor}

The ryanodine receptor of small hive beetle (Atum_Ryr) is predicted to be a 5112 amino acid protein (XP 019871887.1). Mutations in the ryanodine receptor (i.e. E1338D, Q4594L, I4790M, and G4946E) are responsible for high levels of resistance to anthranilic diamide insecticides in the diamondback moth (Pxyl_Ryr $[60,61]$ ). The homologous residues in the predicted SHB ryanodine receptor are either in a susceptible state or homologous to the honey bee ryanodine receptor (Amel_Ryr).

\section{Cys-loop ligand gated ion channels}

A total of $11 \alpha$ and $1 \beta$ nAChR subunits were identified. These predicted nicotinic acetylcholine receptor subunits of Aethina tumida have high similarity in number and protein sequence to those identified in Tribolium $[45,62]$ (Table 1), and this arrangement is similar to the repertoire in other insects (Table 2). The phylogenetic relationship between $\mathrm{nAChR}$ subunits and all other CLGICs from Aethina tumida, Tribolium castanuem, and Apis mellifera is shown in Fig. 1.

There were two predicted transcripts for the $\alpha 3$ ortho$\log$. The alternative transcript possessed a 3 ' intron acceptor splice site variant of intron 10 resulting in a 12 base addition to the $5^{\prime}$ end of the exon 11 at nucleotide 1205 that introduced a 4 amino acid addition (i.e. MSSS: cDNA XM_020016025.1, protein XP_019871584.1) relative to the primary transcript (cDNA XM_020016026.1, protein XP_019871585.1) when compared to the genomic DNA (NW_017853156.1; Fig. 2a). Transcripts of the Tcas $\alpha 3$ subunit in Tribolium also possess an alternative intron splice site, but it introduces a premature stop codon [62].

Two predicted proteins had high identity to Tcas $\alpha 5$. The predicted protein (XP_019867584.1) has the highest identity to Tcas $\alpha 5(90.3 \%)$ and covers a similar span of genomic DNA (Atum 5 , NW_017853036.1, LOC109596473, 39,724 
Table 1 Percent identity and divergence of the predicted protein sequence of nAChRs in Aethina tumida and Tribolium castaneum

\begin{tabular}{|c|c|c|c|c|c|c|c|c|c|c|c|c|}
\hline & Atuma1 & Atuma2 & Atuma3 & Atuma4 & Atuma5 & Atuma6 & Atuma7 & Atuma8 & Atuma9 & Atuma10 & Atuma12 & Atum $\beta 1$ \\
\hline asa1 & $93.0 / 7.4$ & $4 / 68.8$ & $58.8 / 59.0$ & $.0 / 63.0$ & $.0 / 142.7$ & $3.6 / 117.0$ & $34.4 / 135.5$ & $57.4 / 61.2$ & 24.6/199.0 & $25.5 / 193.5$ & $35.5 / 130.3$ & $42.3 / 103.2$ \\
\hline Tcasa2 & 5 & 4 & 2 & $50.3 / 79.1$ & 2.9 & 2.2 & 8.7 & .7 & 6.0 & 8.8 & 9.7 & .7 \\
\hline asa3 & $60.9 /$ & $53.9 /$ & .2 & 5.5 & 38.7 & $38.4 / 117.7$ & $33.5 /$ & $60.8 / 54.9$ & 98.0 & 87.3 & 27.5 & $45.5 / 92.7$ \\
\hline 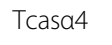 & 5.9 & 3 & 8.2 & 1 & 8.4 & 4.6 & 4.4 & 5 & 01.0 & 85.0 & 36.4 & 95.8 \\
\hline asa5 & $33.5 / 139.8$ & $30.3 / 158.2$ & $32.4 / 145.7$ & $31.3 / 151.8$ & $90.3 / 10.4$ & $36.3 / 126.7$ & $30.7 / 155.5$ & $33.3 / 140.9$ & $21.4 / 230.0$ & 24.8/197.0 & $82.0 / 20.6$ & $33.9 / 138.1$ \\
\hline$x 6$ & 3 & 8.5 & 7.7 & 3.4 & 9.5 & 5.9 & 4.5 & 7.5 & 6.5 & 5.1 & 20.8 & 3 \\
\hline asa7 & $38.6 / 117.1$ & $39.2 / 114.5$ & $39.0 / 115.3$ & $37.5 / 121.2$ & $35.3 / 131.0$ & $68.7 / 40.5$ & $83.5 / 18.7$ & $38.6 / 116.8$ & $23.2 / 211.0$ & 24.9/196.0 & $34.3 / 136.0$ & $35.6 / 129.8$ \\
\hline casa8 & 59.2 & $55.1 / 67.2$ & 2.6 & 8.0 & 33.0/ & $38.2 /$ & $31.7 / 149.6$ & $90.0 / 10.8$ & 21.6 & 26 & 33.7 & 43.6/98.6 \\
\hline ascall & 18.0 & 37.0 & 15.0 & $22.1 / 221.0$ & 234.0 & $21.4 / 230.0$ & 41.0 & 36.0 & 82.4 & 181.7 & 234.0 & $/ 243.0$ \\
\hline Tcasa10 & 27.0/180.9 & /179.2 & 193.5 & 25.4/195.1 & 200.0 & $27.5 / 177.4$ & $26.4 / 186.2$ & 194.1 & $27.0 / 181.5$ & 41.9 & 193.7 & 26.3/186.8 \\
\hline Tcasa11 & $58.8 / 59.0$ & $55.1 / 66.0$ & $63.2 / 50.3$ & $60.4 / 55.7$ & $35.1 / 132.1$ & $39.8 / 112.1$ & $33.4 / 140.3$ & $88.5 / 12.6$ & 21.9/223.0 & $26.7 / 183.8$ & $36.5 / 125.9$ & $45.6 / 92.3$ \\
\hline Tcas $\beta 1$ & $42.9 / 101.1$ & $42.1 / 104.0$ & $45.4 / 93.0$ & $44.0 / 97.5$ & $34.5 / 135.0$ & $37.3 / 122.1$ & $33.5 / 139.8$ & $45.1 / 64.1$ & $21.5 / 228.0$ & $29.2 / 164.9$ & $34.9 / 133.0$ & $98.2 / 1.8$ \\
\hline
\end{tabular}

Putative orthologs are shown in bold

bp; Tcas 5 , 36,436 bp), while XP_019867563.1 only shares $82.0 \%$ identity to Tcas 55 and has a much more compact genomic region (NW_017853036.1, LOC109596454, 2326 bp). This gene is directly adjacent to LOC109596473, but in the reverse orientation on the positive strand, hence the high likelihood of gene duplication. Therefore, it is proposed that XP_019867563.1 is to be named Atuma12.

Only one protein (XP_019867426.1) was predicted to be generated by the Atum $\alpha 6$ locus. More than 18 transcripts of Tcas $\alpha 6$ have been reported [39] and alternative splicing of this gene is highly conserved across insects [69]. A diagram of alternative splicing of Atuma6 is shown in Fig. $2 \mathrm{~b}$. The predicted protein contains the equivalent of exon $3 \mathrm{~b}$. The predicted protein contains exon 8a with high identity (98.1\%) to exon 8a from Tcas $\alpha 6$. An equivalent of exon $8 \mathrm{c}$ is encoded in the genome with $81.8 \%$ identity, but exon $8 \mathrm{c}$ is rarely included in transcripts in other insects [69]. There was no signature of exon $8 \mathrm{~b}$ in the predicted protein, transcript, or genomic sequence when using Tcas $\alpha 6$ exon $8 \mathrm{~b}$ in

Table 2 Comparison of the number and type of nAChR subunits across insect species

\begin{tabular}{lllc}
\hline Species & $a$ & $\beta$ & Reference \\
\hline Aethina tumida, small hive beetle & 11 & 1 & Current Manuscript \\
Anopheles gambiae, malaria mosquito & 9 & 1 & {$[63]$} \\
Apis mellifera, honey bee & 9 & 2 & {$[64]$} \\
Bombyx mori, silkworm moth & 9 & 3 & {$[65]$} \\
Meligethes aeneus, pollen beetle & 8 & 1 & {$[66]$} \\
Drosophila melanogaster, fruit fly & 7 & 3 & {$[67]$} \\
Musca domestica, house fly & 7 & 3 & {$[68]$} \\
Nasonia vitripennis, parasitoid wasp & 12 & 4 & {$[51]$} \\
Tribolium castaneum, red flour beetle & 11 & 1 & {$[45]$} \\
\hline
\end{tabular}

alignments. A BLASTn or tBLASTn searches of the consensus nucleotide and protein sequences of exon $8 \mathrm{~b}$, respectively, did not return any matches. Therefore, it appears that Atuma6 is lacking exon $8 \mathrm{~b}$. This would be an unusual situation, as $8 \mathrm{~b}$ is the most commonly included exon in transcripts of $\alpha 6$ orthologs and is the only exon 8 variant in Bmora6 of Bombyx mori [69]. Transcripts of $\alpha 6$ orthologs are extensively modified by A-to-I RNA-editing [69]. Comparisons of the genomic sequence (NW_017853031.1) to transcript data [70] find no A-to-I RNA editing aside from editing sites 2 and 3 which are constitutively $\mathrm{G}$ in the genome, as in Tribolium and other insects. This is consistent with the reduced number of editing sites of Tcas $\alpha 6$ in Tribolium [62, 69, 71]. Future cloning experiments will likely expand the repertoire of alternative splicing and A-to-I RNA editing of Atum $\alpha 6$ or confirm the reduced posttranscriptional modifications noted here.

The predicted Atuma7 subunit is missing 156 amino acids when compared to Tcas $\alpha 7$ (Fig. 2c). These missing amino acids of Atuma7 occur in a region of the protein that is highly conserved across orthologs and homologs. This region comprises a large portion of the subunit from just after ligand-binding loop B through shortly after TM3. Alignment of the consensus nucleotide sequence of this region from $\alpha 7$ orthologs does not produce any significant matches to the genomic DNA, suggesting this is not a computational error but rather a genomic deletion. Both BLASTp and tBLASTn searches yielded no matches. The lack of many critical features of the Atum $\alpha 7$ subunit indicates the translated protein is either non-functional or performs an alternative activity, such as modulating receptor expression [72] or sequestering acetylcholine at the synapse [73]. The absence of a large region of a nAChR subunit is not unusual, as transcripts of D $\alpha 7$ and Amel $\alpha 7$ had an identical truncated region [64]. 


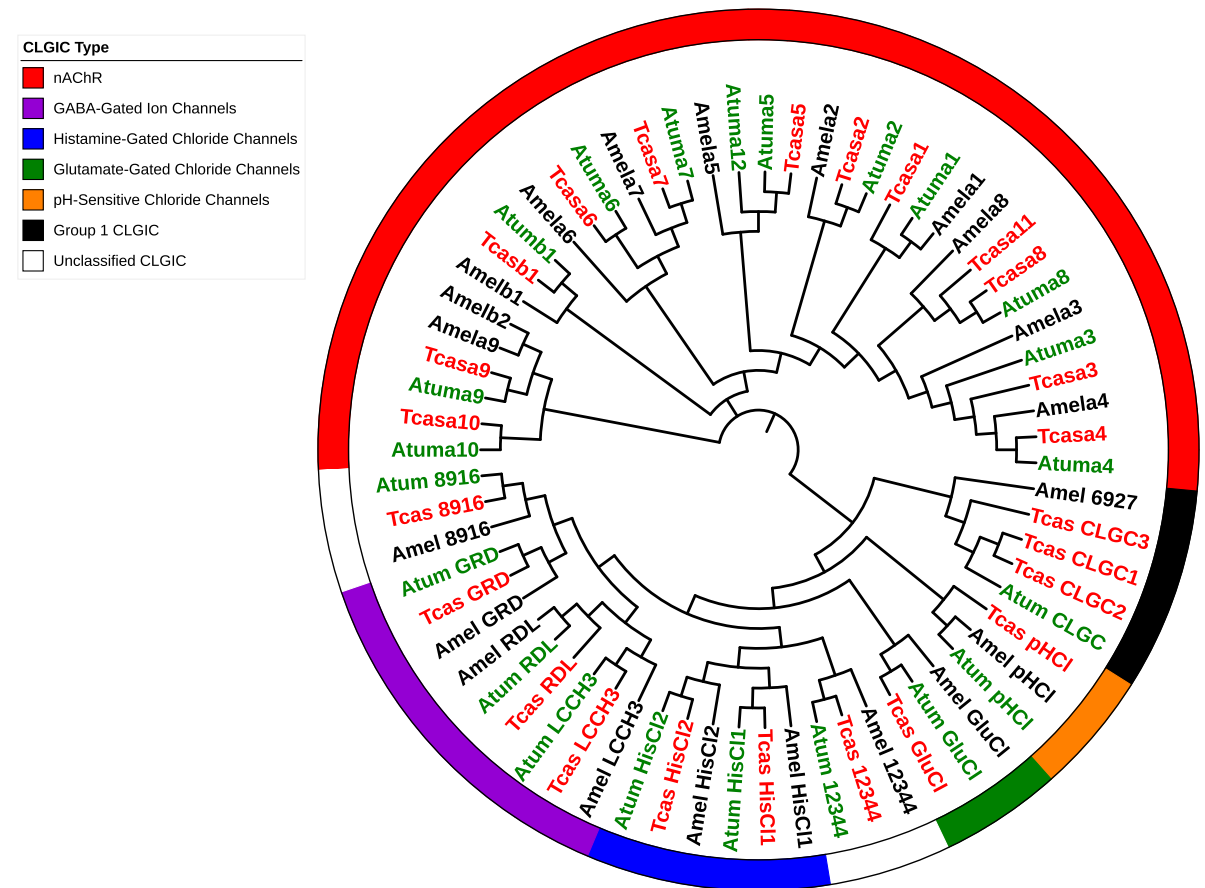

Fig. 1 Phylogenetic relationship of the cys-loop ligand gated ion channel superfamily of the small hive beetle, Aethina tumida (green), red flour beetle, Tribolium castaneum (red), and honey bee, Apis mellifera (black). Genbank accession numbers for the sequences mentioned in this figure can be found in Additional file 1: Table S1

Two predicted nAChR proteins showed identity to Tcas $\alpha 8$ and Tcas $\alpha 11$. Upon examination, these two proteins (XP_019873223.1 and XP_019875406.1) could be merged into a single protein, as the 152 amino acids in the C-terminus of XP_019873223.1 overlapped with the N-terminus of XP_019875406.1 with 100\% identity. This merged protein aligned to the Tcas $\alpha 8$ subunit of Tribolium with $90 \%$ identity, thus the merged protein is identified as Atum $\alpha 8$.

Immediately preceding the channel pore that is comprised of the second transmembrane segment of an nAChR subunit, there is a characteristic GEK amino acid motif that is important for ion selectivity [74]. However, the Atum $\alpha 9$ subunit possesses a KDR amino acid motif, which is similar to other divergent nAChR subunits $[44,45,65]$.

Two predicted proteins shared similarity with Tcas $\alpha 10$ (Table 1). The mRNA sequence for XM_020024668.1 is incomplete at the $5^{\prime}$ end due to an automated translation discrepancy. Comparison of the protein, cDNA, and genomic regions of these predicted proteins shows a very high identity (98.8, 98.0, and 96.9\%, respectively), and the intron positions and length are identical. Therefore, it suggests that XM_020024668.1 is a computational error and may not be an alternative transcript of Atuma10.

The predicted Atum $\beta 1$ ortholog shared $98.2 \%$ identity with $T \operatorname{cas} \beta 1$. The major difference is the absence of 11 amino acids in the intracellular linker between TM3 and TM4 of Atum $\beta 1$ compared to Tcas $\beta 1$. This region is the source of most variation in $\beta 1$ orthologs in other species $[44,45,51,63,75]$.

\section{GABA-gated chloride channels}

The predicted Atum_RDL protein (XP_019870942.1) shared $92.8 \%$ identity to Tcas_RDL and possesses alternative exons $3 \mathrm{a}$ and $6 \mathrm{~b}$. Orthologs of alternative exons 3b, 3c, and 6a of Tcas_RDL [45] were identified in the Atum_RDL genomic sequence (NW_017853131.1), but not in the predicted transcript of Atum_RDL (XM 020015383.1). Another predicted Atum_RDL protein (XP_019879456.1) only shared 81.0\% identity. The latter protein lacked the transmembrane regions, so it is likely non-functional. However, alternative exon usage of this gene may have caused a computational error that yielded this presumably non-functional protein, as it is bound at the $5^{\prime}$ and $3^{\prime}$ ends by alternative exons $3 a$ and $6 a$, respectively. The PAR amino acid motif immediately preceding the TM2 domain that forms the pore of the channel acts as a selectivity filter for anion-selective receptors is observed in Atum_RDL [74]. The RDL subunit also undergoes extensive A-to-I RNA editing that can alter the potency of GABA at the receptor [76]. Comparison of the predicted mRNA to the BLASTmatched transcriptome sequence [70] showed no evidence of A-to-I RNA editing. The A302S mutation in 


A) Atuma3
Transcript XM_020016025.1
Protein XP_019871584.1
Transcript XM_020016026.1
Protein XP_019871585.1

RDL that confers resistance to cyclodienes and fipronil is in the susceptible state in Atum_RDL [43].

Atum_GRD and Atum_LCCH3 shared 80\% identity and $87.9 \%$ to the Tribolium orthologs, respectively. The predicted protein for Atum_GRD contains the variant 1 splice type [45]. Most of the differences in the sequences of these orthologs were in the intracellular linker between TM3 and TM4. Unlike the PAR selectivity motif of RDL, the Atum_GRD and Atum_LCCH3 subunits possess ADR and SAR amino acid motifs, respectively. This is consistent with the Tribolium orthologs of these proteins [45].

\section{Glutamate-gated chloride channels}

Five splice variants of the Atum glutamate-gated chloride channels (Atum_GluCl) were predicted. The Atum $\mathrm{GluCl} \mathrm{x} 1, \mathrm{x} 3$, and $\mathrm{x} 5$ variants yielded highly similar proteins. Of this group, $\mathrm{x} 3$ protein was missing K371, which is in the intracellular linker between TM3 and TM4. While the $\mathrm{x} 1$ and $\mathrm{x} 5$ proteins were $100 \%$ identical, the 5 'UTR differed between these transcripts. The $x 1, x 3$, and $\mathrm{x} 5$ transcripts contained alternative exon $3 \mathrm{~b}$, while $\mathrm{x} 2$ and $\mathrm{x} 4$ possessed alternative exons $3 \mathrm{a}$ and $3 \mathrm{c}$, respectively. Atum_GluCl exon $3 \mathrm{c}$ appears to be a beetle-specific exon, as it has not been reported in transcripts from other insects besides Tribolium $[44,45,51,77]$.

\section{pH-sensitive chloride channels}

The annotation predicted seven distinct Atum_pHCl proteins that varied due to putative alternative splicing in regions of the intracellular linker between TM3 and TM4 (Fig. 3 and Table 3). Exon 9a and 9b of the open reading frame exhibits cassette exons where either one, both, or neither are present. These transcript types have been previously reported as splice variants 3 or 3 a [44, $45,49,51]$, however, the co-occurrence of both exons 9a 


\section{A)}

Atum_pHCl Exon 9a Atum_pHCl Exon 9b Atum_pHCl Exon 9a+b Atum_pHCl Exon 9x Tcas_pHCl Variant 3 Tcas_pHCl Variant 3a

B)

Atum_pHCl
Atum_pHCl intron 10 donor
Atum_pHCl intron 10 acceptor

Atum_pHC Atum_pHCl intron 10 acceptor

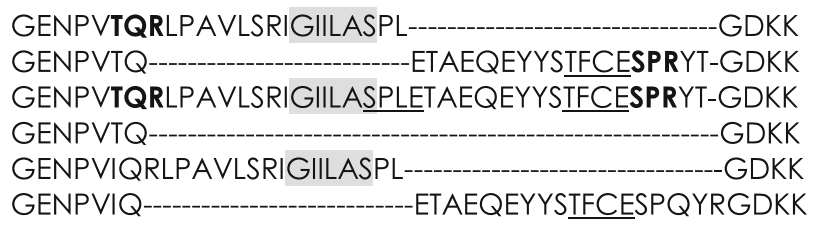

CAAE---------------'VRKK
CAAEVNIN-------VRKK
CAAE-------SCLLQVRKK

Fig. 3 Transcript variants of Atum_pHCl. a Amino acid sequence of splice variants due to alternative splicing of exon 9 in Atum_pHCl compared to Tcas_pHCl [45]. Sequence motifs in bold are protein kinase-C phosphorylation sites, underlined motifs are casein kinase II phosphorylation sites, and shaded motifs are $\mathrm{N}$-myristoylation sites. $\mathbf{b}$ Amino acid sequence of splice variants due to alternative splicing of intron 10 in Atum_pHCl. The corresponding sequence in Tcas_pHCl is identical to the regular splice variant

and $9 \mathrm{~b}$ in a single transcript, as in variants $\mathrm{x} 1-3$, is a novelty. These alternative exons possess additional protein kinase $\mathrm{C}$ phosphorylation sites. There is an $\mathrm{N}$-myristoylation site on exon 9a. Exon 9b adds a casein kinase II phosphorylation site. The case of the inclusion of both exons $9 \mathrm{a}$ and $\mathrm{b}$ gives rise to an additional casein kinase II phosphorylation site that spans the conjoined exons. A further source of variation was observed with alternative splicing of the donor and acceptor sites of intron 10 . A 12 bp extension of the donor site in transcript $\mathrm{x} 2$ adds an additional 4 amino acids (i.e. VNIN) and remains in frame. The acceptor site may be spliced $15 \mathrm{bp}$ upstream to add 5 amino acids (i.e. SCLLQ). These intron splice variants do not add sites for post-translational modifications. Splice variant 4 that modifies residues in the extracellular ligand-binding loop $\mathrm{C}$ was not predicted in any of these proteins [44, 45, 51]. Up to 16 transcripts are possible using combinations of alternative splicing of exon 9 and intron 10.

\section{Histamine-gated chloride channels}

The Atum_HisCl1 and Atum_HisCl2 proteins possess the PAR amino acid motif at the extracellular pore of the channel that regulates anion selectivity [74]. The

Table 3 Alternative splicing characteristics of Atum_pHCl transcripts

\begin{tabular}{lcccc}
\hline Atum_pHCl Transcript & Exon 9a & Exon 9b & $\begin{array}{c}\text { Intron 10 } \\
\text { Donor }\end{array}$ & $\begin{array}{c}\text { Intron 10 } \\
\text { Acceptor }\end{array}$ \\
\hline x1 & $x$ & $x$ & - & $x$ \\
$\times 2$ & $x$ & $x$ & $x$ & - \\
$\times 3$ & $x$ & $x$ & - & - \\
$\times 4$ & - & $x$ & - & $x$ \\
$\times 5$ & $x$ & - & - & $x$ \\
$x 6$ & - & - & - & $x$ \\
$\times 7$ & - & - & - & - \\
\hline
\end{tabular}

Atum_HisCl1 and Atum_HisCl2 proteins share 86.6 and $84.1 \%$ identity with their respective orthologs in Tribolium (Tcas_HisCl1 ABU63602.1; Tcas_HisCl2 ABU63603.1).

\section{Phenolamine receptors}

The phylogenetic relationship of phenolamine receptors in SHB compared to other insects is shown in Fig. 4. One $\alpha$-andregenic-like and $3 \beta$-andregenic-like octopamine receptor subunits as well as orthologs of tyramine receptors 1 and 2 were identified in the SHB genome. The predicted proteins contain the hallmarks of phenolamine receptors. These features include the conserved DRY sequence at the end of the third transmembrane segment that is critical for receptor activation, as well as a pair of cysteine residues in the extracellular loops that stabilize receptor structure. These receptor subunits are extensively modified by post-translational modifications that affect receptor desensitization and internalization [78]. The locations and types of post-translational modifications are shown in Table 4.

\section{Discussion}

The small hive beetle is an increasingly invasive pest of honey bee colonies across the globe. Due to its intimate relationship with honey bees, it is likely that SHBselective chemical control measures will become valuable tools to manage the impacts of this pest on honey bee colonies. This in silico study describes the SHB orthologs for many of the known insecticide target sites that will identify target sites that can be exploited for SHB-specific control and facilitate the development of molecular techniques to evaluate potential mechanisms of insecticide resistance in this pest.

DSC1 and its orthologs are highly expressed in the antennae and brain [22,79], and it has been shown to be critical for odor detection [23, 24]. Small hive beetle 


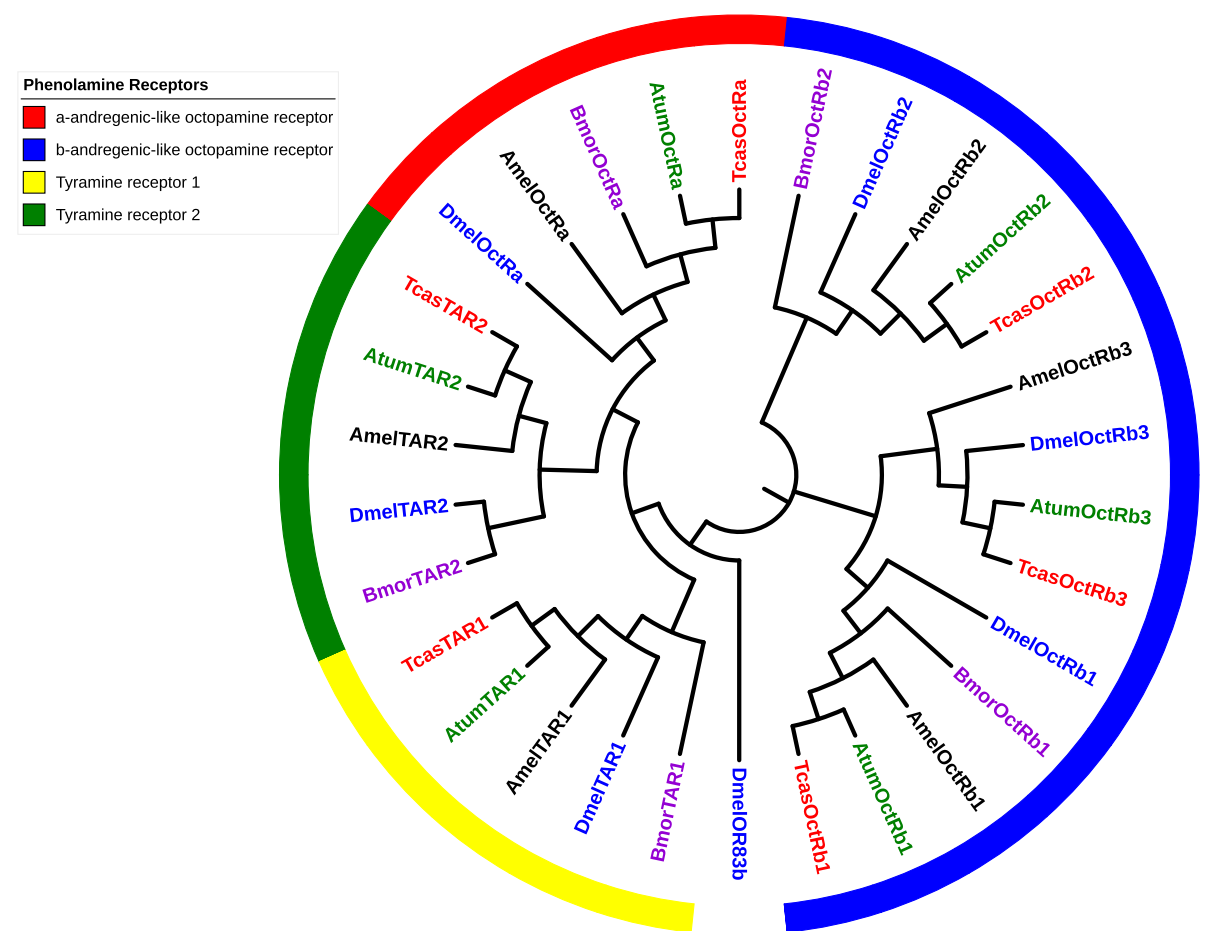

Fig. 4 Phylogenetic relationship of octopamine and tyramine receptors in small hive beetle, Aethina tumida (green), red flour beetle, Tribolium castaneum (red), honey bee, Apis mellifera (black), fruit fly, Drosophila melanogaster (blue), and silk worm, Bombyx mori (purple). Genbank accession numbers for the sequences mentioned in this figure can be found in Additional file 1: Table S1

adults aggregate to mate and lay eggs by the attraction to volatile alcohols that are emitted as larval feeding ferments honey via the symbiotic yeast Kodamaea ohmeri [5]. Therefore, a molecule that can specifically inhibit AtumSC1 may interfere with the attraction to these volatile compounds and reduce the SHB infestation rate.

The ryanodine receptor in SHB superficially appears similar to that in honey bees, prima facie. However, there are dramatic differences in the binding affinity of diamide insecticides to ryanodine receptors among insect species. Increased binding affinity of diamide insecticides to ryanodine receptors is correlated with higher mortality among species [80]. Honey bees lack a high affinity binding site for flubendiamide (a diamide insecticide) that is present on the ryanodine receptors of Lepidopteran pests [30]. However, the exact region or mutation of the honey bee ryanodine receptor that is responsible for this lack of high affinity binding has not been determined. While in silico comparison is inconclusive, pharmacological studies comparing diamide binding affinity of SHB and honey bee ryanodine receptors will be able to identify differences in binding affinity among these receptors. Ryanodine receptor pharmacology is uncharacterized in SHB at this time.

The cys-loop ligand-gated ion channels represent the target sites for many of the most commonly used insecticide classes (i.e. neonicotinoids, spinosyns, sulfoximines, avermectins, and fiproles) as well as for new insecticide classes under development (i.e. isoxazolines, metadiamides, cycloxaprid, and mesoionics). Insecticides acting at the cysloop ligand-gated ion channels account for approximately $40 \%$ of insecticide sales [81]. Despite the breadth of insecticides currently used and those under development that act at this diverse group of target sites, there may only be limited options for species-specific control of SHB. For example, honey bees have very low sensitivity to the neonicotinoids acetamiprid and thiacloprid [82]. Evaluating the sensitivity of small hive beetle to these compounds may present an opportunity for selective control. Other insecticides that act at the cys-loop ligand-gated ion channels such as spinosad, fipronil, and avermectin are extremely toxic to honey bees [32, 83, 84]. Selectivity for SHB with these compounds is likely to be based on differences in spatial exposure rather than physiological differences in the target sites for these compounds, as observed in the effectiveness of Apithor traps that are impregnated with fipronil for SHB control $[14,85]$.

Mutations in octopamine receptors have been identified in amitraz-resistant populations of the southern cattle tick, Rhipicephalus microplus [57, 58]. Upon further examination, the putative octopamine receptor that was mutated in the amitraz-resistant Santa Luiza strain is more closely related to tyramine receptor 1 than a bona fide octopamine receptor. The T8P and L22S mutations that were 
Table 4 Location and number of types of post-translational modifications of octopamine receptors in Aethina tumida. The residues involved in post-translational modifications is shown below and the amino acid position in the peptide of the first residue in the motif is shown as a number

\begin{tabular}{|c|c|c|c|c|c|c|}
\hline $\begin{array}{l}\text { Octopamine } \\
\text { Receptor Subunit }\end{array}$ & $\begin{array}{l}N \text {-linked } \\
\text { glycosylation }\end{array}$ & $\begin{array}{l}\text { Casein kinase II } \\
\text { phosphorylation }\end{array}$ & $\begin{array}{l}\text { Protein kinase C } \\
\text { phosphorylation }\end{array}$ & $\begin{array}{l}\mathrm{N}- \\
\text { myristoylation }\end{array}$ & Amidation & $\begin{array}{l}\text { CAMP- and CGMP-dependent } \\
\text { protein kinase phosphorylation }\end{array}$ \\
\hline Atum_OctaR & $\begin{array}{l}\text { NATA } 6 \\
\text { NSTL } 171 \\
\text { NGSN } 272 \\
\text { NSTT } 275 \\
\text { NNSL } 528\end{array}$ & $\begin{array}{l}\text { TDPE } 20 \\
\text { TLQE } 173 \\
\text { SSCD } 371 \\
\text { TGRE } 376 \\
\text { SSCD } 387 \\
\text { SLGD530 }\end{array}$ & $\begin{array}{l}\text { SSK } 52 \\
\text { SHK } 137 \\
\text { TTR } 224 \\
\text { TTK } 234 \\
\text { TLR } 251 \\
\text { SGK } 261 \\
\text { SNR } 289 \\
\text { SHR } 361 \\
\text { SSR } 366 \\
\text { SRR } 367 \\
\text { TGR } 376 \\
\text { SRK } 398 \\
\text { SRR } 502\end{array}$ & $\begin{array}{l}\text { GSPHSN } 267 \\
\text { GSNSTT } 273 \\
\text { GIIVGG } 424 \\
\text { GSDGSQ } 505 \\
\text { GGDPSD } 538\end{array}$ & $\begin{array}{l}\text { SGKR } 261 \\
\text { MGKR } 401\end{array}$ & $\begin{array}{l}\text { RRSS } 363 \\
\text { RRSS } 368 \\
\text { RRGS } 503\end{array}$ \\
\hline Atum_Oct $\beta 1 R$ & $\begin{array}{l}\text { NETD } 17 \\
\text { NNTS } 26 \\
\text { NTSI } 27 \\
\text { NFSV } 107 \\
\text { NRTY } 214 \\
\text { NYSN } 402 \\
\text { NASS } 405 \\
\text { NISE } 432\end{array}$ & $\begin{array}{l}\text { TFSE } 6 \\
\text { STNE } 15 \\
\text { TDFD } 19 \\
\text { SWE } 109 \\
\text { TTSD } 194 \\
\text { SENE } 434\end{array}$ & $\begin{array}{l}\text { SLR } 276 \\
\text { SSK } 296 \\
\text { TSK } 385\end{array}$ & $\begin{array}{l}\text { GISAGL } 269 \\
\text { GIIVSA } 310\end{array}$ & & \\
\hline Atum_Oct $\beta 2 R$ & $\begin{array}{l}\text { NITV } 3 \\
\text { NVTN } 7 \\
\text { NATS } 10 \\
\text { NFSV } 85 \\
\text { NTTY } 190 \\
\text { NNTN } 240 \\
\text { NSTL } 333\end{array}$ & $\begin{array}{l}\text { TSTE } 12 \\
\text { TTEE } 170 \\
\text { TNGD } 242 \\
\text { TLHE } 258 \\
\text { SDLD } 369\end{array}$ & $\begin{array}{l}\text { TKK } 141 \\
\text { SSK } 253 \\
\text { SIR } 380 \\
\text { SDR } 399\end{array}$ & $\begin{array}{l}\text { GSSKTL } 252 \\
\text { GIIMGI } 290\end{array}$ & & $\begin{array}{l}\text { RRPS } 377 \\
\text { RRCS } 401\end{array}$ \\
\hline Atum_Oct $\beta 3 R$ & $\begin{array}{l}\text { NATL } 19 \\
\text { NRTN } 24 \\
\text { NVTN } 27 \\
\text { NASV } 101\end{array}$ & $\begin{array}{l}\text { TNIE } 29 \\
\text { TTNE } 187 \\
\text { SYRE } 262 \\
\text { SDGE } 275\end{array}$ & $\begin{array}{l}\text { THR } 158 \\
\text { SYR } 262 \\
\text { TIR } 292 \\
\text { SWR } 299\end{array}$ & $\begin{array}{l}\text { GQINGR } 283 \\
\text { GIIMGA } 311\end{array}$ & NGRR 286 & RRST 288 \\
\hline Atum_TAR1 & $\begin{array}{l}\text { NTSC } 3 \\
\text { NFST } 13 \\
\text { NQST } 236 \\
\text { NNTH } 286\end{array}$ & $\begin{array}{l}\text { SCVD } 5 \\
\text { TPRE } 241 \\
\text { SHED } 295 \\
\text { SLTD } 299\end{array}$ & $\begin{array}{l}\text { TYK } 55 \\
\text { TLK } 141 \\
\text { TKR } 217 \\
\text { TPR } 241 \\
\text { SRR } 310 \\
\text { SPK } 340 \\
\text { TKK } 352 \\
\text { SRR } 410\end{array}$ & $\begin{array}{l}\text { GNFSTI } 12 \\
\text { GIDICK } 97 \\
\text { GXGATK } 348 \\
\text { GIIMGV } 381\end{array}$ & & RRNS 311 \\
\hline Atum_TAR2 & $\begin{array}{l}\text { NESS } 3 \\
\text { NNTA } 32 \\
\text { NKSS } 327 \\
\text { NSTI } 404\end{array}$ & $\begin{array}{l}\text { SSLE } 7 \\
\text { SDVD } 260 \\
\text { SECE } 267 \\
\text { REPE } 341\end{array}$ & $\begin{array}{l}\text { TTR } 72 \\
\text { TRR } 73 \\
\text { SRK } 154 \\
\text { SKR } 159 \\
\text { TRK } 246 \\
\text { STK } 249 \\
\text { SLR } 312 \\
\text { SFR } 363 \\
\text { TVK } 441 \\
\text { TRR } 448\end{array}$ & GLTVAT 20 & & $\begin{array}{l}\text { KRRS } 156 \\
\text { RKST } 247 \\
\text { RRET } 365\end{array}$ \\
\hline
\end{tabular}

associated with amitraz resistance occur in the $\mathrm{N}$ terminus of the receptor [57]. This section is highly divergent and no SHB phenolamine receptor aligns to this region. Therefore, these mutations are not informative for determining potential amitraz-insensitivity in SHB. However, the I61F mutation in the octopamine $\beta$-andregeniclike receptor 2 observed in amitraz-resistant populations of Rhiphecephalus microplus occurs at a highly conserved residue that is in the susceptible state in SHB [58]. With the widespread and intense use of amitraz to control Varroa mites in honey bee colonies, it will be of interest to observe changes in amitraz sensitivity in SHB.

\section{Conclusions}

The global wax trade acts as a conduit for the introduction of SHB to honey bee colonies across the globe [3]. 
As the impacts of SHB on beekeeping operations intensifies, the use of chemical control measures will surely become part of a comprehensive SHB control program. Over-reliance on insecticides will undoubtedly select for insecticide resistance and reduce the effectiveness of these tools for SHB control. The insecticide target sites in the SHB genome described here and elsewhere [17] provide a susceptible benchmark for designing molecular diagnostic tools to identify and monitor changes in resistance alleles. As more reports of insecticide sensitivity are made available, potential differences in toxicity between SHB and honey bees may be explained by differences in target sites.

\section{Methods}

\section{Gene identification and sequence alignments}

The predicted proteins from the official gene set of Aethina tumida (NCBI Bioproject PRJNA256171) was queried with Tribolium castaneum orthologs using a BLASTp search [86]. Putative orthologs in Aethina tumida were designated by $>95 \%$ query coverage and $E$-value $<1 \mathrm{e}^{-100}$. Sequence files were annotated with EditSeq and aligned with MegAlign (DNAStar LaserGene 13 Package, Madison WI). A complete list of insecticide target site orthologs in SHB and other species is found in Additional file 1: Table S1.

Alternative splicing was performed by aligning the predicted transcript to the genomic region. Intron boundaries were identified by the GT-AG intron donor and acceptor consensus sequences [87]. Putative A-to-I RNA editing sites were identified by aligning the genomic sequence to the sequence derived from the SHB transcriptome (NCBI Bioproject PRJNA361278 [70]). A-to-I RNA editing in AtumSC1 [26], Atum $\alpha 6$ nAChR [69], and Atum_RDL [76] was compared to previously reported editing sites.

Alignments of cys-loop ligand-gated ion channel subunits and phenolamine (i.e. octaopamine and tyramine) receptors were made with MEGAv7.0.21 [88] using the Gonnet Protein Weight Matrix with Gap Opening and Gap Extension penalties of 10 and 0.2, respectively. The alignment was used to construct a Neighbor-Joining Tree [89] with 1000 bootstrap replications [90]. Trees for CLGIC and phenolamine receptors were visualized and annotated with the iTOL online tool [91]. Posttranslational-modifications of phenolamine receptors were examined with ScanProsite tool [92].

\section{Supplementary information}

Supplementary information accompanies this paper at https://doi.org/10. 1186/s12864-020-6551-y.

Additional file 1: Table S1. List of NCBI Genbank (www.ncbi.nlm.nih. gov) accession numbers for genes of insecticide target sites in the genome of $A$. tumida and orthologs in other species that are mentioned in this manuscript.

\section{Abbreviations}

Ace: Acetylcholinesterase; BLAST: Basic Local Alignment Search Tool;

$\mathrm{Ca}^{2+}$ : Calcium ion; CLGIC: Cys-loop ligand-gated ion channels;

DDT: Dichlorodiphenyltrichloroethane; DSC1: Drosophila Sodium Channel 1:

GABA: Gamma-aminobutyric acid; GluCl: Glutamate-gated chloride channels; GRD: Gamma-aminobutyric acid receptor alpha-like; HisCl: Histamine-gated chloride receptors; LCCH3: Gamma-aminobutyric acid receptor subunit betalike; mRNA: messenger ribonucleic acid; nAChR: nicotinic acetylcholine receptors; $\mathrm{Na}_{\mathrm{v} 1}$ : Voltage-gated sodium channel; $\mathrm{pHCl}$ : $\mathrm{pH}$-sensitive chloride channels; RDL: Resistance to dieldrin; RNA: Ribonucleic acid; SC1: Sodium channel 1; SHB: Small hive beetle; TM: Transmembrane; UTR: Untranslated region

\section{Acknowledgements}

We thank Arian Avalos and Perot Selau of the USDA-ARS Honey Bee Breeding, Genetics, and Physiology Laboratory in Baton Rouge LA and Jay Evans of USDA-ARS Bee Research Lab in Beltsville MD for valuable discussions and critique of this manuscript. Mention of trade names or commercial products in this publication is solely for the purpose of providing specific information and does not imply recommendation or endorsement by the USDA. USDA is an equal opportunity provider and employer.

Authors' contributions

FDR and LB conceived the project, performed the research, and wrote the manuscript. Both authors have read and approved the manuscript.

\section{Funding}

No extramural funding was supplied.

\section{Availability of data and materials}

The datasets used and/or analysed during the current study available from the corresponding author on reasonable request. A list of GenBank accession numbers for genes, transcripts, and proteins analyzed in this study is found in Additional file 1: Table S1.

\section{Ethics approval and consent to participate}

Not Applicable, previously generated sequencing data only was used in this research.

\section{Consent for publication}

Not Applicable.

\section{Competing interests}

The authors declare that they have no competing interests.

Received: 3 October 2019 Accepted: 31 January 2020

Published online: 12 February 2020

\section{References}

1. Al Toufailia H, Alves DA, Bená DC, Bento JM, Iwanicki NS, Cline AR, Ellis JD, Ratnieks FL. First record of small hive beetle, Aethina tumida (Murray), in South America. J Apic Res. 2017;56(1):76-80.

2. Lee S, Hong K-J, Cho YS, Choi YS, Yoo M-S, Lee S. Review of the subgenus Aethina Erichson s. str.(Coleoptera: Nitidulidae: Nitidulinae) in Korea, reporting recent invasion of small hive beetle, Aethina tumida. J Asia Pac Entomol. 2017;20(2):553-8.

3. Idrissou FO, Huang Q, Yañez O, Neumann P. International beeswax trade facilitates small hive beetle invasions. Sci Rep. 2019;9(1):10665.

4. Elzen P, Westervelt D, Causey D, Ellis J, Hepburn H, Neumann P. Method of application of tylosin, an antibiotic for American foulbrood control, with effects on small hive beetle (Coleoptera: Nitidulidae) populations. J Econ Entomol. 2002;95(6):1119-22.

5. Hayes RA, Rice SJ, Amos BA, Leemon DM. Increased attractiveness of honeybee hive product volatiles to adult small hive beetle, Aethina tumida, resulting from small hive beetle larval infestation. Entomologia Exp Appl. 2015;155(3):240-8.

6. Neumann P, Elzen PJ. The biology of the small hive beetle (Aethina tumida, Coleoptera: Nitidulidae): gaps in our knowledge of an invasive species. Apidologie. 2004;35(3):229-47. 
7. Neumann P, Pirk C, Hepburn H, Solbrig A, Ratnieks F, Elzen P, Baxter J. Social encapsulation of beetle parasites by cape honeybee colonies (Apis mellifera capensis Esch.). Naturwissenschaften. 2001;88(5):214-6.

8. Neumann P, Härtel S. Removal of small hive beetle (Aethina tumida) eggs and larvae by African honeybee colonies (Apis mellifera scutellata). Apidologie. 2004;35(1):31-6.

9. Mustafa SG, Spiewok S, Duncan M, Spooner-Hart R, Rosenkranz P. Susceptibility of small honey bee colonies to invasion by the small hive beetle, Aethina tumida (Coleoptera, Nitidulidae). J Appl Entomol. 2014;138(7):547-50.

10. Elzen P, Baxter J, Neumann P, Solbrig A, Pirk C, Hepburn H, Westervelt D, Randall C. Behaviour of African and European subspecies of Apis mellifera toward the small hive beetle, Aethina tumida. In: Inter-and intraspecific parasitism in honeybees (Apis mellifera $\mathrm{L}$ ): the small hive beetle (Aethina tumida Murray) and the Cape honeybee (A m capensis Esch); 2001. p. 25.

11. Frake AM, De Guzman LI, Rinderer TE. Comparative resistance of Russian and Italian honey bees (Hymenoptera: Apidae) to small hive beetles (Coleoptera: Nitidulidae). J Econ Entomol. 2009;102(1):13-9.

12. Ellis JD, Hepburn R, Luckman B, Elzen PJ. Effects of soil type, moisture, and density on pupation success of Aethina tumida (Coleoptera: Nitidulidae). Environ Entomol. 2004;33(4):794-8.

13. Bernier M, Fournier V, Eccles L, Giovenazzo P. Control of Aethina tumida (Coleoptera: Nitidulidae) using in-hive traps. Can Entomol. 2015;147(1):97-108.

14. Levot G, Somerville D, Annand N, Collins D, Barchia I. A six-month-long assessment of the health of bee colonies treated with APITHOR ${ }^{\text {TM }}$ hive beetle insecticide. J Apic Res. 2015;54(4):386-93.

15. Hillesheim E, Ritter W, Bassand D. First data on resistance mechanisms of Varroa jacobsoni (Oud.) against tau-fluvalinate. Exp Appl Acarol. 1996;20(5): 283-96.

16. Elzen $P$, Westervelt D. Detection of coumaphos resistance in Varroa destructor in Florida. Am Bee J. 2002;142(4):291-2.

17. Evans JD, McKenna D, Scully E, Cook SC, Dainat B, Egekwu N, Grubbs N, Lopez D, Lorenzen MD, Reyna SM, et al. Genome of the small hive beetle (Aethina tumida, Coleoptera: Nitidulidae), a worldwide parasite of social bee colonies, provides insights into detoxification and herbivory. GigaScience. 2018;7(12):giy138.

18. Kim K, Kim SH, Yoon KA, Cho YS, Yoo M-S, Lee SH. Characterization of the small hive beetle transcriptome focused on the insecticide target site and RNA interference genes. J Asia Pac Entomol. 2018;21(4):1256-61.

19. Salkoff L, Butler A, Wei A, Scavarda N, Giffen K, Ifune C, Goodman R, Mandel G. Genomic organization and deduced amino acid sequence of a putative sodium channel gene in Drosophila. Science. 1987;237:744-9.

20. Zhou W, Chung I, Liu Z, Goldin A, Dong K. A voltage-gated calciumselective channel encoded by a sodium channel-like gene. Neuron. 2004;42(1):101-12.

21. Zhang T, Liu Z, Song W, Du Y, Dong K. Molecular characterization and functional expression of the DSC1 channel. Insect Biochem Mol Biol. 2011:41:451-8

22. Gosselin-Badaroudine $P$, Moreau $A$, Simard $L$, Cens T, Rousset M, Collet C, Charnet $\mathrm{P}$, Chahine M. Biophysical characterization of the honeybee DSC1 orthologue reveals a novel voltage-dependent $\mathrm{Ca}^{2+}$ channel subfamily: Cay4. J Gen Physiol. 2016. https://doi.org/10.1085/jgp.201611614.

23. Kulkarni NH, Yamamoto AH, Robinson KO, Mackay TFC, Anholt RRH. The DSC1 channel, encoded by the smi60E locus, contributes to odor-guided behavior in Drosophila melanogaster. Genetics. 2002;161:1507-16.

24. Zhang T, Wang Z, Wang L, Luo N, Jiang L, Liu Z, Wu CF, Dong K. Role of the DSC1 channel in regulating neuronal excitability in Drosophila melanogaster: extending nervous system stability under stress. PLoS Genet. 2013;9(3): e1003327.

25. Rinkevich FD, Du Y, Tolinski J, Ueda A, Wu C-F, Zhorov BS, Dong K. Distinct roles of the DmNa $\vee$ and DSC1 channels in the action of DDT and pyrethroids. Neurotoxicology. 2015;47:99-106.

26. Dong K, Du Y, Rinkevich F, Wang L, Xu P. The Drosophila Sodium Channel 1 (DSC 1): the founding member of a new family of voltage-gated cation channels. Pestic Biochem Physiol. 2015;120:36-9.

27. Cui Y-J, Yu L-L, Xu H-J, Dong K, Zhang C-X. Molecular characterization of DSC1 orthologs in invertebrate species. Insect Biochem Mol Biol. 2012:42:353-9.

28. Sattelle DB, Cordova D, Cheek TR. Insect ryanodine receptors: molecular targets for novel pest control chemicals. Invertebr Neurosci. 2008;8(3):107.
29. Lahm GP, Stevenson TM, Selby TP, Freudenberger JH, Cordova D, Flexner L, Bellin CA, Dubas CM, Smith BK, Hughes KA. Rynaxypyr ${ }^{\mathrm{rm}}$ : a new insecticidal anthranilic diamide that acts as a potent and selective ryanodine receptor activator. Bioorg Med Chem Lett. 2007;17(22):6274-9.

30. Qi S, Casida JE. Species differences in chlorantraniliprole and flubendiamide insecticide binding sites in the ryanodine receptor. Pestic Biochem Physiol. 2013;107(3):321-6.

31. Dinter A, Brugger KE, Frost N-M, Woodward MD. Chlorantraniliprole (Rynaxypyr): a novel DuPont ${ }^{\mathrm{TM}}$ insecticide with low toxicity and low risk for honey bees (Apis mellifera) and bumble bees (Bombus terrestris) providing excellent tools for uses in integrated pest management. Julius-Kühn-Archiv. 2010;423:84.

32. Zhu YC, Adamczyk J, Rinderer T, Yao J, Danka R, Luttrell R, Gore J. Spray toxicity and risk potential of 42 commonly used formulations of row crop pesticides to adult honey bees (Hymenoptera: Apidae). J Econ Entomol. 2015;108(6):2640-7.

33. Connolly C, Wafford K. The Cys-loop superfamily of ligand-gated ion channels: the impact of receptor structure on function. Biochem Soc Trans. 2004;32:529-34.

34. Gauthier M. State of the art on insect nicotinic acetylcholine receptor function in learning and memory. In: Insect Nicotinic Acetylcholine Receptors. New York: Springer; 2010. p. 97-115.

35. Fayyazuddin A, Zaheer MA, Hiesinger PR, Bellen HJ. The nicotinic acetylcholine receptor Dalpha7 is required for an escape behavior in Drosophila. PLoS Biol. 2006;4(3):e63.

36. Jeschke P, Nauen R. Neonicotinoid insecticides. In: Gilbert LI, latrou K, Gill SS, editors. Comprehensive Molecular Insect Science, vol. 5. New York: Elsevier; 2005. p. 53-105.

37. Sparks TC, Watson GB, Loso MR, Geng C, Babcock JM, Thomas JD. Sulfoxaflor and the sulfoximine insecticides: chemistry, mode of action and basis for efficacy on resistant insects. Pestic Biochem Physiol. 2013;107(1):1-7.

38. Salgado VL, Sparks TC. The spinosyns: chemistry, biochemistry, mode of action, and resistance. In: Gilbert LI, latrou K, Gill SS, editors. Comprehensive Molecular Insect Science. Boston: Elsevier; 2005. p. 137-73.

39. Rinkevich FD, Chen M, Shelton AM, Scott JG. Transcripts of the nicotinic acetylcholine receptor subunit gene Pxyla6 with premature stop codons are associated with spinosad resistance in diamondback moth, Plutella xylostella. Invertebr Neurosci. 2010;10:25-33.

40. Liu Z, Williamson MS, Lansdell SJ, Denholm I, Han Z, Millar NS. A nicotinic acetylcholine receptor mutation conferring target-site resistance to imidacloprid in Nilaparvata lugens (brown planthopper). Proc Natl Acad Sci. 2005;102(24):8420-5.

41. Bloomquist JR. Chloride channels as tools for developing selective insecticides. Arch Insect Biochem Physiol. 2003;54:145-56.

42. Casida JE. Insecticide action at the GABA-gated chloride channel: recognition, progress, and prospects. Arch Insect Biochem Physiol. 1993:22(1-2):13-23.

43. Ffrench-Constant RH, Anthony-Nicola A, Aronstein K, Rocheleau T, Stilwell G. Cyclodiene insecticide resistance: From molecular to population genetics. Annu Rev Entomol. 2000;45:449-66.

44. Jones AK, Sattelle DB. The cys-loop ligand-gated ion channel superfamily of the honeybee, Apis mellifera. Invertebr Neurosci. 2006;6:123-32.

45. Jones AK, Sattelle DB. The cys-loop ligand-gated ion channel gene superfamily of the red flour beetle, Tribolium castaneum. BMC Genomics. 2007:8:327.

46. Bloomquist JR. GABA and Glutamate Receptors as Biochemical Sites for Insecticide Action. In: Ishaaya I, editor. Biochemical Sites of Insecticide Action and Resistance. Heidelberg: Springer-Verlag Berlin; 2001. p. 17-41.

47. Kane NS, Hirschberg B, Qian S, Hunt D, Thomas B, Brochu R, Ludmerer SW, Zheng Y, Smith M, Arena JP, et al. Drug-resistant Drosophila indicate glutamate-gated chloride channels are targets for the antiparasitics nodulisporic acid and ivermectin. PNAS. 2000;97(25):13949-54.

48. Gisselmann G, Pusch H, Hovemann BT, Hatt H. Two cDNAs coding for histamine-gated ion channels in D. melanogaster. Nat Neurosci. 2002;5(1):11-2.

49. Schnizler K, Saeger B, Pfeffer C, Gerbaulet A, Ebbinghaus-Kintscher U, Methfessel C, Franken E-M, Raming K, Wetzel CH, Saras A. A novel chloride channel in Drosophila melanogaster is inhibited by protons. J Biol Chem. 2005;280(16):16254-62.

50. Sarthy PV. Histamine: a neurotransmitter candidate for Drosophila photoreceptors. J Neurochem. 1991;57(5):1757-68. 
51. Jones AK, Bera AN, Lees K, Sattelle DB. The cys-loop ligand-gated ion channel gene superfamily of the parasitoid wasp, Nasonia vitripennis. Heredity. 2010;104:247-59.

52. Zheng Y, Hirschberg B, Yuan J, Wang AP, Hunt DC, Ludmerer SW, Schmatz DM, Cully DF. Identification of two novel Drosophila melanogaster histamine-gated chloride channel subunits expressed in the eye. J Biol Chem. 2002;277(3):2000-5.

53. Farooqui T. Review of octopamine in insect nervous systems. Open Access Insect Physiol. 2012;4:1-17.

54. Ohta H, Ozoe Y. Molecular signalling, pharmacology, and physiology of octopamine and tyramine receptors as potential insect pest control targets. In: Advances in Insect Physiology, vol. 46. Waltham: Elsevier; 2014. p. 73-166.

55. Evans PD, Gee JD. Action of formamidine pesticides on octopamine receptors. Nature. 1980;287(5777):60.

56. Kita T, Hayashi T, Ohtani T, Takao H, Takasu H, Liu G, Ohta H, Ozoe F, Ozoe $Y$. Amitraz and its metabolite differentially activate $\alpha$-and $\beta$-adrenergic-like octopamine receptors. Pest Manag Sci. 2017;73(5):984-90.

57. Chen AC, He H, Davey RB. Mutations in a putative octopamine receptor gene in amitraz-resistant cattle ticks. Vet Parasitol. 2007;148(3-4):379-83.

58. Corley SW, Jonsson NN, Piper EK, Cutullé C, Stear MJ, Seddon JM. Mutation in the RmßAOR gene is associated with amitraz resistance in the cattle tick Rhipicephalus microplus. Proc Natl Acad Sci. 2013;110(42):16772-7.

59. Amichot M, Castella C, Cuany A, Berge JB, Pauron D. Target modification as a molecular mechanism of pyrethroid resistance in Drosophila melanogaster. Pestic Biochem Physiol. 1992:44:183-90.

60. Troczka B, Zimmer CT, Elias J, Schorn C, Bass C, Davies TE, Field LM, Williamson MS, Slater R, Nauen R. Resistance to diamide insecticides in diamondback moth, Plutella xylostella (Lepidoptera: Plutellidae) is associated with a mutation in the membrane-spanning domain of the ryanodine receptor. Insect Biochem Mol Biol. 2012;42(11):873-80.

61. Guo L, Liang P, Zhou X, Gao X. Novel mutations and mutation combinations of ryanodine receptor in a chlorantraniliprole resistant population of Plutella xylostella (L.). Sci Rep. 2014;4:6924

62. Rinkevich FD, Scott JG. Transcriptional diversity and allelic variation in nicotinic acetylcholine receptor subunits of the red flour beetle, Tribolium castaneum. Insect Mol Biol. 2009;18:233-42.

63. Jones AK, Grauso M, Sattelle DB. The nicotinic acetylcholine receptor gene family of the malaria mosquito, Anopheles gambiae. Genomics. 2005;85:176-87.

64. Jones AK, Raymond-Delpech V, Thany SH, Gauthier M, Sattelle DB. The nicotinic acetylcholine receptor gene family of the honey bee, Apis mellifera. Genome Res. 2006;16(11):1422-30.

65. Shao Y-M, Dong K, Zhang C-X. The nicotinic acetylcholine receptor gene family of the silkworm, Bombyx mori. BMC Genomics. 2007:8:324-33.

66. Zimmer C, Maiwald F, Schorn C, Bass C, Ott MC, Nauen R. A de novo transcriptome of European pollen beetle populations and its analysis, with special reference to insecticide action and resistance. Insect Mol Biol. 2014;23(4):511-26

67. Littleton JT, Ganetzky B. Ion channels and synaptic organization: analysis of the Drosophila genome. Neuron. 2000;26:35-43.

68. Scott JG, Warren WC, Beukeboom LW, Bopp D, Clark AG, Giers SD, Hediger M, Jones AK, Kasai S, Leichter CA, et al. Genome of the house fly, Musca domestica L., a global vector of diseases with adaptations to a septic environment. Genome Biol. 2014;15(10):1.

69. Jin Y, Tian N, Cao J, Liang J, Yang Z, LV J. RNA editing and alternative splicing of the insect nAChR subunit alpha6 transcript: evolutionary conservation, divergence and regulation. BMC Evol Biol. 2007;7:98.

70. Tarver MR, Huang Q, de Guzman L, Rinderer T, Holloway B, Reese J, Weaver $D$, Evans JD. Transcriptomic and functional resources for the small hive beetle Aethina tumida, a worldwide parasite of honey bees. Genomics Data. 2016:9:97-9

71. Jones A, Brown L, Sattelle D. Insect nicotinic acetylcholine receptor gene families: from genetic model organism to vector, pest and beneficial species. Invertebr Neurosci. 2007:7:67-73.

72. Saragoza PA, Modir JG, Goel N, French KL, Li L, Nowak MW, Stitzel JA. Identification of an alternatively processed nicotinic receptor a7 subunit RNA in mouse brain. Mol Brain Res. 2003;117(1):15-26.

73. Smit AB, Syed NI, Schaap D, van Minnen J, Klumperman J, Kits KS, Lodder H, van der Schors RC, van Elk R, Sorgedrager $B$, et al. A glia-derived acetylcholine-binding protein that modulates synaptic transmission. Nature. 2001;411:261-8.
74. Jensen ML, Schousboe A, Ahring PK. Charge selectivity of the Cys-loop family of ligand-gated ion channels. J Neurochem. 2005;92(2):217-25.

75. Jones AK, Sattelle DB. Diversity of Insect Nicotinic Acetylcholine Receptor Subunits. In: Thany S.H. (eds) Insect Nicotinic Acetylcholine Receptors. Advances in Experimental Medicine and Biology, 2010 vol 683. p25-43. New York: Springer.

76. Jones AK, Buckingham SD, Papadaki M, Yokota M, Sattelle BM, Matsuda K, Sattelle DB. Splice-variant and stage-specific RNA editing of the Drosophila GABA receptor modulates agonist potency. J Neurosci. 2009;29:4287-92.

77. Semenov EP, Pak WL. Diversification of Drosophila chloride channel gene by multiple post-transcriptional mRNA modifications. J Neurochem. 1999;72(1):66-72

78. Ferguson SS. Evolving concepts in G protein-coupled receptor endocytosis: the role in receptor desensitization and signaling. Pharmacol Rev. 2001:53(1):1-24.

79. Anholt RRH, Lyman RF, Mackay TFC. Effects of single P-element insertion on olfactory behavior in Drosophila melanogaster. Genetics. 1996;143:293-301.

80. Qi S, Lümmen P, Nauen R, Casida JE. Diamide insecticide target site specificity in the Heliothis and Musca ryanodine receptors relative to toxicity. J Agric Food Chem. 2014;62(18):4077-82.

81. Sparks TC, Nauen R. IRAC: mode of action classification and insecticide resistance management. Pestic Biochem Physiol. 2015:121:122-8.

82. Iwasa T, Motoyama N, Ambrose JT, Roe M. Mechanism for the differential toxicity of neonicotinoid insecticides in the honey bee, Apis mellifera. Crop Prot. 2004;23:371-8.

83. Li X, Bao C, Yang D, Zheng M, Li X, Tao S. Toxicities of fipronil enantiomers to the honeybee Apis mellifera $\mathrm{L}$. and enantiomeric compositions of fipronil in honey plant flowers. Environ Toxicol Chem. 2010;29(1):127-32.

84. Mayes MA, Thompson GD, Husband B, Miles MM. Spinosad toxicity to pollinators and associated risk. Rev Environ Contam Toxicol. 2003;179:37-71.

85. Levot GW, Somerville D. Efficacy and safety of the insecticidal small hive beetle refuge trap APITHOR ${ }^{\text {TM }}$ in bee hives. Aust Entomol. 2012:51(3):198-204.

86. Altschul SF, Gish W, Miller W, Myers EW, Lipman DJ. Basic local alignment search tool. J Mol Biol. 1990:215:403-10.

87. Mount SM, Burks C, Herts G, Stormo GD, White O, Fields C. Splicing signals in Drosophila: intron size, information content, and consensus sequences. Nucleic Acids Res. 1992;20(16):4255-62.

88. Kumar S, Stecher G, Tamura K. MEGA7: Molecular Evolutionary Genetics Analysis version 7.0 for bigger datasets. Mol Biol Evol. 2016. https://doi.org/ 10.1093/molbev/msw054.

89. Saitou N, Nei M. The neighbor-joining method: a new method for reconstructing phylogenetic trees. Mol Biol Evol. 1987:4(4):406-25.

90. Felsenstein J. Confidence limits on phylogenies: an approach using the bootstrap. Evolution. 1985;39:783-91.

91. Letunic I, Bork P. Interactive tree of life (iTOL) v3: an online tool for the display and annotation of phylogenetic and other trees. Nucleic Acids Res. 2016:44(W1):W242-5.

92. Hulo N, Bairoch A, Bulliard V, Cerutti L, De Castro E, Langendijk-Genevaux PS, Pagni M, Sigrist CJ. The PROSITE database. Nucleic Acids Res. 2006;34(suppl 1):D227-30.

\section{Publisher's Note}

Springer Nature remains neutral with regard to jurisdictional claims in published maps and institutional affiliations.

Ready to submit your research? Choose BMC and benefit from:

- fast, convenient online submission

- thorough peer review by experienced researchers in your field

- rapid publication on acceptance

- support for research data, including large and complex data types

- gold Open Access which fosters wider collaboration and increased citations

- maximum visibility for your research: over $100 \mathrm{M}$ website views per year

At BMC, research is always in progress.

Learn more biomedcentral.com/submission 